\title{
How to govern the urban hydrosocial cycle: archaeo-genealogy of hydromentalities in the Swiss urban water sector between 1850 and 1950
}

\author{
P. Rattu and R. Véron \\ Institute of Geography and Sustainability, University of Lausanne, Géopolis, 1015 Lausanne, Switzerland
}

Correspondence to: P. Rattu (paola.rattu@unil.ch) and R. Véron (rene.veron@unil.ch)

\begin{abstract}
Received: 18 October 2013 - Revised: 18 September 2014 - Accepted: 29 September 2014 - Published: 5 February 2015
\end{abstract}
Abstract. Switzerland appears to be a privileged place to investigate the urban political ecology of tap water because of the specificities of its political culture and organization and the relative abundance of drinking water in the country. In this paper, we refer to a Foucauldian theorization of power that is increasingly employed in the social sciences, including in human geography and political ecology. We also implement a Foucauldian methodology. In particular, we propose an archaeo-genealogical analysis of discourse to apprehend the links between urban water and the forms of governmentality in Switzerland between 1850 and 1950. Results show that two forms of governmentality, namely biopower and neoliberal governmentality, were present in the water sector in the selected period. Nonetheless, they deviate from the models proposed by Foucault, as their periodization and the classification of the technologies of power related to them prove to be much more blurred than Foucault's work, mainly based on France, might have suggested.

\section{Introduction}

The relatively recent field of urban political ecology (UPE; cf. Heynen et al., 2006) provides a thorough conceptual framework for apprehending urban water. For instance, the concept of the hydrosocial cycle (Swyngedouw, 2009) conceives urban water as a "hybrid" (Swyngedouw, 1999:444445), a "techno-nature" (Giglioli and Swyngedouw, 2008) possessing both a physical and a social component that co-construct each other. Urban water, thus, simultaneously shapes urban politics, conflicts and power differentials and is shaped by them. This conceptualization at the core of the sub-field of the urban political ecology of water has inspired a wide geo-historical research activity (cf. Swyngedouw, 1997, 2004; Kaika, 2003, 2012; Giglioli and Swyngedouw, 2008).

However, recent literature proposes a new perspective on urban water. Focusing on the relations between urban water and power, Foucauldian scholars have started investigating the archaeologies of urban water and the genealogies of the forms of governmentality linked to them (cf. for instance Babu, 2009; Page, 2005; von Schnitzler, 2008).
Governmentality has been theorized by Foucault (2008:186) as "the way in which one conducts the conduct of men", i.e., the way in which power is exerted through different methods, techniques and tools called technologies of power (Foucault, 1977). Various forms of governmentality exist, as this concept has been used "to grasp the birth and the characteristics of a whole variety of ways of problematizing and acting on individual and collective conduct in the name of certain objectives which do not have the State as their origin or point of reference" (Rabinow and Rose, 2006:200).

In the domain of the political ecology of water, Hellberg (2014:1) has proposed the concept of hydromentality to indicate "the mentalities, rationalities and techniques through which water users, as well as water use, are governed."

Tap water distribution in Switzerland constitutes a promising case study for the application of a Foucauldian framework. In fact, as it will be shown below, some characteristics of neoliberal governmentality are central elements of the Swiss political system in general, and evidence from the literature suggests the existence of a form of neoliberal hydromentality in the tap water sector at least since the first 
decades of the 20th century. In addition, others forms of governmentality (e.g., biopower) seem to have been implemented in the tap water sector.

The consensus-based Swiss democratic style and the relative abundance of water in the country might help explain the fact that the only major conflicts over tap water distribution date back to the 19th century, while nowadays no overt conflicts over urban tap water distribution exist in Switzerland. The absence of conflict also makes the case study relevant for the implementation of a Foucauldian perspective, as the geohistorical study of non-conflictive hydrosocial cycles might cast light over peaceful and fair socioeconomic dynamics.

This research aims to use a Foucauldian conceptual framework for apprehending the urban political ecology of tap water distribution in Switzerland between 1850 and 1950, i.e., to understand which mentalities, rationalities and techniques have governed water users and water use during the selected period in Switzerland. This historical perspective should contribute to highlight how the exercise of power has changed over time and in which ways it has shaped the urban hydrosocial cycles in Switzerland and their perception.

The next section presents some central features of the Swiss tap water sector and political system in light of governmentality and further explains the interest of carrying on a Foucauldian research on tap water in Switzerland for the subfield of the UPE of water and for Foucauldian studies. Then, a methodological section presents the employed archaeogenealogical method and the selected data. The results section presents the archaeology of urban water in Switzerland during the selected period, while the discussion section presents a genealogy of forms of governmentality in the light of the selected conceptual framework. The conclusion synthetizes results, discusses the limits of the study and contains propositions for further research.

\section{Switzerland: a promising case study for a Foucauldian UPE of water}

\subsection{Governmentality in the Swiss water sector}

In Switzerland, as in many other developed countries, the history of urban tap water starts between the second half of the 19th and the beginning of the 20th century (Reynard, 2005). At that time, Swiss cities faced fast demographic expansion (Reynard, 2008), rapid economic development based on tourism (Tissot, 2000; for a case study on Lausanne, see Humair, 2007) and industrialization (cf. Lebeau, 1960, on Zurich). These demographic and economic developments were accompanied by a series of epidemics, particularly water-borne and water-related ones such as typhus (for a case study on Vaud, see Heller, 1979; on Valais, see Vouilloz Burnier, 2008), that are also testified in historical documents (cf. De La Harpe, 1867; Morax, 1868). It was at that time when the provision of piped drinking water became a critical topic. Consequently, the first water companies and water utility companies were established in this period (Reynard et al., 2000; Reynard, 2008).

When piped water networks were created, the municipality monopolized in many cases the provision of water, and public debate focused on the financing of these distribution networks (Pflieger, 2009b). In other cases, the municipalities allowed private companies to invest directly in urban water provision. Sometimes more than one company emerged in the same city, each owning and operating their own "municipal" water distribution network. However, they did not always have enough customers to benefit from scale economies and faced strong criticisms (especially concerning hygiene, prices, network maintenance et accountability) towards the end of the 19th century (Pflieger, 2009b). The municipalities eventually took over the provision of water in the early 20th century (for an example on Lausanne, see Pflieger, 2009b).

Since the second half of the 19th century, as the urban population grew, the need to find new water sources had become imperative. The subsequent additional capture of water from lakes, rivers and springs in the nearby countryside (Reynard, 2005, 2008) required additional investment, fomenting competition and conflict between private water companies. Moreover, capturing lake and river water generated strong resistance from parts of the population accustomed to drinking springwater (e.g., Heller, 1979:41-46; Duc, 2003a). Lake water was considered "standing water" and even labeled as "corpses' juice" (Heller, 1979:44, own translation). This view started changing only at the end of the 19th century, after the spread of virulent springwater-borne epidemics questioned the "healthiness" of those water sources (Pflieger, 2009b). During the first decades of the 20th century, the transformation of lake water into tap water thus became progressively accepted and opposition gradually ceased to exist.

Most research on drinking water provision in Switzerland has been written from a historical-institutional perspective which provides very useful geo-histories of local hydrosocial cycles. Particular attention is given to entrepreneurial strategies, political debates, oppositional attitudes of upper classes, as well as economic and legal constraints relevant for the evolution of water institutions. An important part of this literature focuses on the emergence and the evolution of the specific water provision systems in Swiss cities (e.g., Reynard, 2005, 2008; Reynard et al., 2000). Other studies analyze the role of particular key actors and key organizations in the field of drinking water provision in Switzerland (e.g., Dirlewanger, 1998; Duc, 2003a, b). Other interesting research shows how water utilities helped create and reinforce institutional constructions such as "municipalism"1, so

\footnotetext{
1"Municipalism" is here understood as a movement towards a public municipal management of utility services such as electricity, gas and water distribution. In the water sector, municipalism has been motivated by the willingness to guarantee a fair water distribution (as in other European countries), and it has subsequently
} 
typical for Switzerland (cf. Pflieger, 2009a, b; Paquier and Pflieger, 2008).

Yet, some Swiss historians drew a portrait of the history of accessing water that is closer to a (Foucauldian) UPE perspective than to the more common historical-institutional approach. For instance, Heller (1979) describes the progressive implementation of piped water networks in the Frenchspeaking part of Switzerland in connection with the ubiquitous installation of water closets and of public and private bathrooms at the end of the 19th century. This is interpreted as an important part of the hygienist project of keeping the working class healthy, ameliorating humankind and moralizing the crowds (Heller, 1979). This analysis, particularly the references to hygiene and body care, directly relates to the Foucauldian concept of biopower (cf. Foucault, 1997, 2009; Rabinow and Rose, 2006), as the establishment of water networks seems to have been linked to the determination of government to control the bodies (particularly of the lower classes) through the dissemination of particular water practices. Biopower is used to apprehend "more or less rationalized attempts to intervene upon the vital characteristics of human existence" (Rabinow and Rose, 2006:196). In particular, Foucault (1997) defines biopower as a form of power (i.e., a form of governmentality) interested in knowing and regulating the life and morbidity of populations, i.e., in surveying and controlling, at the social (and not individual) scale, all the factors that could influence the behavior of the inhabitants of a given territory, including birth rate, mortality and healthiness. According to Foucault (1997), biopower emerged at the end of the 18th century focusing on the relations between the population and its living environment, particularly in urban areas.

Furthermore, Heller (1979) identifies a social paternalism toward the working classes and she describes the social segregation of water infrastructures in urban Switzerland between the end of the 19th and the beginning of the 20th century. This historical analysis confirms that water can be a means to express socioeconomic differences and conflicts, and it resonates with the concept of the hydrosocial cycle. Heller's work can, therefore, be seen as a proto-UPE analysis of urban water in Switzerland.

For a comprehensive UPE on urban water in Switzerland, however, a more systematic analysis of the different forms of governmentality in the domain needs to be undertaken. To our knowledge, no such analysis exists currently. In particular, the existing (historical) literature refers only to biopower while more recently a new form of governmentality was promoted by neoliberalism (Foucault, 2008). While biopower and biopolitics focused on managing and maximizing the life of human individuals and populations, neoliberal governmentality is centered on economics and rationality. More precisely, neoliberal governmentality was fashioned accord-

been managed according to principles of scale economies, profit and territorial integration (Pflieger, 2009b). ing to two principles, namely the fact that "the overall exercise of political power can be modeled on the principles of a market economy" (Foucault, 2008:131), and the fact that individuals are accorded an "artificially arranged" liberty (Lemke, 2001:200), in order to responsibilize them and to shape their behaviors at a distance through the manipulation of specific technologies of power and the related incentives (Foucault, 1979, 1991, 2008; Fletcher, 2010; Lemke, 2001; Ferguson and Gupta, 2002). Neoliberal governmentality has been widely theorized and applied, including to apprehend the relations between individuals, power and the environment (cf. Agrawal, 2005; Brand, 2007; Fletcher, 2010).

In Switzerland, some striking components of an early form of neoliberal governmentality related to tap water seem to exist. For instance, the historically documented interest in keeping the finances of water utilities separate from other municipal accounts follows what many would call a "neoliberal logic" today. Furthermore, households were made to pay for water connections and for water usage (cf. Pflieger, 2009b; Paquier and Pflieger, 2008), an early example of "user charges" for a public good. These practices could constitute an "economicization" (Gorz, 1989 cited in Hood, 1995) of water, meaning the expansion of the sphere of economic rationality to (initially) non-economic areas.

Considering these specificities, applying a Foucauldian framework for apprehending the UPE of the tap water distribution in Switzerland would allow the analysis of the various forms of governmentality, their patterns and their temporalities, and this might contribute to the knowledge of Swiss urban tap water hydrosocial cycles. In addition, new Foucauldian theorizations of governmentalities might emerge if the ante tempora presence of a form of neoliberal governmentality is highlighted.

\subsection{Absence of conflict in the tap water sector}

Tap water distribution has almost never been perceived as a conflictive matter in Switzerland, except for the abovementioned conflicts at the end of the 19th century regarding the management of water utilities and the social, cultural and economic acceptability of capturing lake water for drinking purposes. Two factors might largely contribute to an explanation of the absence of overt conflicts over drinking water, namely the high volumes of the resource and the consensual political culture of the country.

First, with the exception of a few relatively dry regions (e.g., the canton of Valais) and relatively infrequent drought periods (cf. Pfister, 1988; Schorer, 1992), water is abundant in Switzerland. The high precipitation and the capabilities of the mountain regions to store water in form of ice and snow have motivated geographers since the 19th century to refer to the Alps as the "Europe's water tower" (Michelet, 1868:41-50). This metaphor has been adopted by Swiss academics and the population (cf. Hauser, 1916:419). Nowadays Switzerland is referred to as the "water tower of Europe" 
in scientific debates (e.g., Reynard, 2008; Schädler, 2008; Loutan and Genton, 2006), official discourses (e.g., Geiger and OFEV, 2003) and political speeches (e.g., Delamuraz, 1989). The large amounts of water resources available on Switzerland's surface and in its ground are perceived as a fundamental characteristic of the country so that water also plays a key role in national identity.

Second, political consensus is the main or one of the main characteristics of Swiss governance, alongside direct democracy, federalism and neutrality (Kriesi, 1998:11). Political consensus can be conceptualized as a "general agreement" that refers to the culture of a group, a "pattern of cognitive, affective, and evaluational orientations toward political objects among the members of a group" (Lijphart, 1998:99-100). Accommodation, that is, the "desire to come to amicable understandings" and to "avoid conflict" (Church, 2004:183 and 185), is a key element of the Swiss political style. Some researchers even go as far as to state that Switzerland's specificity is to be "a nation based on the desire of collaboration" inside its borders (Ratti, 1995:118, own translation). The numerous formal and informal consultations institutionalized in the Swiss policy-making process (cf. Church, 2004) certainly help build consensus on policies and laws (Ratti, 1995). The Swiss "concordance system", that is, collaboration and collegiality in decision-making among the members of the Swiss multi-party directorial federal government (Kriesi, 1998), is associated with direct democracy, but it has also been shaped by historical contingencies favoring communalism and collective decision-making (Linder, 2010) and influenced by other institutional constraints such as "integral bicameralism, federalism and elective system" (Kriesi, 1998:227). Although the Swiss inclusive political system has often been seen as non-conflictual and able to integrate conflicting views into consensual decisions, forms of resistance and dissent (as diverse as boycotts, street demonstrations or violent attacks) are also present in Switzerland (Church, 2004).

The apparent absence of overt conflicts, power struggles and injustices represents a challenge for a conventional UPE analysis of urban tap water in Switzerland. This paper therefore adopts a Foucauldian framework that allows examining a case in which conflict and unfairness seem to be very rare or absent. Yet, the presence of covert forms of resistance in the Swiss urban hydrosocial cycles cannot be excluded. The adoption of a Foucauldian UPE of water might be useful for apprehending such phenomena, as they are probably performed at the level of micro-powers and in the domestic relation between the subject and the resource. In applying a Foucauldian approach, this study extends the field of UPE to contexts in which unfairness and struggles are not visible a priori.

\section{Methods}

In order to understand which forms of governmentality have been present in the domain of tap water in Switzerland, if and how they have changed and for which reasons, we applied a method based on discourse analysis. Discourse analysis is widely employed in the field of political ecology (Benjaminsen and Svarstad, 2009), and Foucault (1992) recommended using this method for analyzing the history of the forms of governmentality.

Our research focuses on the years between 1850 and 1950 . The selection of these two time benchmarks is motivated by historical reasons. Around 1850, modern urban water networks started being conceived and realized throughout Europe, while in 1950 the context had radically changed: Switzerland was more or less entirely equipped with modern urban tap water infrastructure and the focus started to shift from water provision to pollution and the elimination of wastewater. Thus, across the selected period, it should be possible to follow the emergence, stabilization and eventual decline of different forms of governmentality since the beginning of modern urban water networks and until before the major changes of the 1950s.

The archives of two Lausanne-based Swiss newspapers, La Gazette de Lausanne (GL, which later became Le Temps) and Feuille d'avis de Lausanne (FAL, which later became 24 Heures), were used for extracting discourses on urban water. The GL archives were used as main primary sources while the FAL archives were used for supporting and checking the findings from GL.

GL contains discourses on urban water in the entire French-speaking part of Switzerland and beyond (i.e., German-speaking part of Switzerland). In addition, this newspaper was one of the central places of expression of liberal and neoliberal thought at the end of the 19th and at the beginning of the 20th century (cf. Mornati, 2010) that could have contributed to promote individual responsibility as a way of governing society. Moreover, GL's complete archives dating back to 1798 have been digitized, allowing for subsequent research.

The archives of the two selected newspapers were searched by two research assistants by intervals of 10 years. As the material found for the years 1860 to 1920 appeared to be particularly dense, this period was eventually subdivided into intervals of five years.

The keyword eau (water) was used and non-pertinent articles (i.e., those in which the word "water" was used as part of common expressions) were excluded. Only articles and advertisements in relation to water and water networks in Switzerland and in the rest of the world have been selected. A synthesis of collected documents is presented in Table 1 .

An archaeo-genealogical method has been applied to the collected discourse. This method is used to identify the emergence and decline of particular lines of arguments within a discourse (Foucault, 1992). Foucault described the archaeo- 
Table 1. Synthesis of the material selected for the research (number of articles per year).

\begin{tabular}{|c|c|c|c|c|c|c|c|c|c|c|c|c|c|c|c|c|c|c|}
\hline Journal & 1850 & 1860 & 1865 & 1870 & 1875 & 1880 & 1885 & 1890 & 1895 & 1900 & 1905 & 1910 & 1915 & 1920 & 1930 & 1940 & 1950 & TOT \\
\hline GL & 5 & 26 & 26 & 27 & 17 & 33 & 24 & 33 & 29 & 62 & 31 & 30 & 14 & 8 & 35 & 30 & 33 & 463 \\
\hline FDA & 5 & 2 & - & 25 & - & 21 & - & 91 & - & 154 & - & 83 & - & 47 & 60 & 45 & 54 & 587 \\
\hline Total & 10 & 28 & 26 & 52 & 17 & 54 & 24 & 124 & 29 & 216 & 31 & 113 & 14 & 55 & 95 & 75 & 87 & 1050 \\
\hline
\end{tabular}

logical and the genealogical phases of research as possessing a slightly different emphasis, the first one being more descriptive and the second one more interpretative (cf. Kendall and Wickham, 1999; Dean, 1994). Foucault considered the two phases as complementary and he did not clearly distinguish them (Kendall and Wickham, 1999). For this reason, we define our method generally as archaeo-genealogical.

Foucault (1992) conceptualized discourse as a research object per se. Discourse is a dynamic construct formed by units called statements (énoncés), which are composed by series of words pronounced or written at a given moment.

Statements are not defined as a structure (such as a phrase, a paragraph, etc.), but as

a function [...] by which one can decide [...] through analysis or intuition, if "they make sense" or not [...]; a function that crosses a domain of possible structures and units and that makes them appear, with concrete contents, in time and space (Foucault, 1992:120, own translation).

More precisely, sequences of words (be they articles, sentences or entire paragraphs) need to possess two characteristics for being considered statements: (1) to have a coherent meaning, i.e., to "make sense" (cf. Foucault, 1992:120); (2) to be inserted in a network of relations (such as references, modifications, contradictions) with other elements, which can be other statements as well as rules, beliefs and contradictions. Those elements constitute the context of the statement, i.e., its "referential" (référentiel, Foucault, 1992:126), which is what "gives the sentence its meaning" and qualifies it as a truth (Foucault, 1992:126, own translation).

Besides the referential, each statement also establishes relations to an associated discursive domain, exclusively composed by other statements, which is what Foucault (1992:136) calls a champ énonciatif. The discursive domain allows distinguishing the uniqueness of each statement, as inside its domain a statement appears as a "singular element" (Foucault, 1992:136, own translation).

In our research, we considered statements on the sequences of words such as the following:

Le gouvernement de Saint Gall vient de faire exécuter divers travaux aux sources de Pfaeffers, pour obtenir une plus grande quantité d'eau. Il a fait de nouveau encaisser les anciennes sources, ce qui a élevé le rendement à quatre mille pieds cubes par minute. ${ }^{2}$ (Gazette de Lausanne, 10 August 1860:1).

The referential of this statement is composed by all statements, rules and beliefs relative to the scarcity of water in this canton, the need of more water and the undertaken actions in the domain. The discursive domain of the statement is much wider and includes, for instance, all the statements referring to the scarcity of water in general at the time, to the measures undertaken elsewhere in the same domain, to the water needs as they were perceived and conceived at the time. The referential of discourse allows linking discourse to the effective conducts and beliefs practiced and perceived at a specific moment in history.

Our archaeo-genealogical method included a first preliminary reading of the selected newspaper articles in order to recognize the general discursive referentials to which the different statements referred to. A second, more critical, reading was used to identify the statements and their links to the referentials. Descriptive files were compiled on the content of each decade, allowing for an archaeology of discourses on urban tap water. For the genealogical part of the research, a third, critical reading of documents and files was used to define discursive domains and to identify links between those discursive domains and various forms of hydromentality. The descriptive files were updated with this information. Based on the conceptualization of the various forms of governmentality, we used these links to define the "general regime" (Foucault, 1992:160, own translation) to which statements had to conform, specifically which forms of governmentality they referred to.

Understandable criticism might be expressed on this method, as it does not implement widespread tools in discourse analysis such as grids and coding of discourse. Nevertheless, the intuitive approach proposed in this article appears as the closest to the one implemented by Foucault himself, who developed the complex and extensive conceptualization summarized above, but gave only few insights on the way of transposing it into practice (Foucault, 1992). This research being a tentative case study based on a purely Foucauldian UPE of water, we decided to test this methodology despite the criticism this might provoke.

\footnotetext{
${ }^{2}$ English translation: "The government of Saint Gall recently carried out works at the springs of Pfäfers in order to obtain a larger quantity of water. It encased the ancient springs again, increasing the output at one thousand cubic feet per minute".
} 
Furthermore, we attribute little importance to the authors or producers of statements. As Foucault (1992:132, own translation) puts it, the analysis of statements "does not imply analyzing the relations between the author and what he said (or wanted to say, or said without wanting it), but to identify in which position an individual needs to be in order to be the subject of it". Even though the archaeo-genealogical method only accords a limited role to the author or producer of statements, Foucault (1992) underlines the importance of investigating their legitimacy, i.e., who has legitimacy (due to his or her status, institutional or physical location and attitude) to speak about a specific subject at a given place and time.

In practice, information on the authors of the documents (newspaper articles, editorials, guest editorials, advertisements and readers' letters) and of the statements that we selected for this research is very limited or absent. Their names are often not mentioned, the journalists in charge of a subject can vary and they are not necessarily the original authors of the statements (for instance, in the case of interviews or public speeches cited in the articles).

Nonetheless, the documents give some indication of the producers of statements (in addition to the journalists) and their legitimacy status. During the 1850 s, owners and managers of water springs advertised their products (bottled water or, in the case of thermal springs, medical and leisure values) in the press. Starting from the 1860s and during all of the second half of the 19th century, other actors came to the floor (namely medical doctors, engineers, military and public officers,) to talk about the water-related epidemics that hit the country and (together with private entrepreneurs) about the need to establish modern water networks. During the first half of the 20th century, at a time when water networks were consolidated and private home-based access to tap water became widely generalized, politicians and public officers were the most present in the discursive production. By contrast, advertisements for spring and thermal water progressively disappeared during the 20th century, as well as the statements on water-related epidemics. Private entrepreneurs also stopped expressing themselves on urban tap water, as it gradually became publicly operated by municipal utilities. Around 1950, finally, researchers and activists come forward to produce a new discourse on pollution and the treatment of wastewater.

Even though some prominent actors can be identified as major producers of discourse, the institutional context of Switzerland complicates the construction of statements and discursive domains. In fact, direct democracy allows the population to express its approval or rejection of particular discourses and propositions at the polls. This political architecture gives citizens legitimacy to pronounce themselves on numerous topics.

Given this political-institutional context, and as our research does not focus on a particular population group, we did not differentiate between statements based on the legit- imacy of their authors. In addition, it seems reasonable to postulate that the publication of these statements in widely diffused newspapers indicates that a large part of the population - probably the majority - could understand and relate to them and that they did not represent obscure argumentations. Thus, these statements seem to be reliable elements for identifying discursive referentials and their evolution.

\section{An archaeology of urban tap water in Switzerland between 1850 and 1950}

The statements that have been collected and analyzed in this research can be regrouped in four main groups, depending on their subjects. The content of each group is synthetized in the paragraphs below and some sentences, translated by us, are provided as illustrations. Even though the statements presented here are all drawn from the GL archives, the archives of FDA have been used to confirm the information provided by GL.

\subsection{Good water: water as medical treatment and medicine}

Numerous statements (advertisements and newspaper articles) present mountain springwater and especially thermal water as having medical properties to treat and prevent a variety of diseases. In the $1850 \mathrm{~s}$, a medical business developed around natural thermal springs and baths in Switzerland. At its beginnings, this was limited to in situ treatments, such as baths and showers at thermal spas. Then, in the 1860s, bottled water from thermal spas started being sold to (mainly wealthy) urban dwellers in Switzerland and abroad. Until the beginning of the 20th century, bottled water was uniquely depicted as a medical treatment, the first advertisement for bottled water without any reference to health appearing only in 1910 (GL, 3 May 1910:4). And only in 1950, information on the exact composition of bottled water became mandatory by law. References to sickness and health became less and less prominent, but the first advertisement of a thermal spa without any such reference did not appear before 1930 (GL, 14 January 1930:6) and other advertisements continued to allude to the curative value of thermal baths at least until the 1950s. While in the second half of the 19th century the urban population of Lausanne disposed of cleansing public baths (such as the Buanderie Haldimand), new urban spas appeared in Lausanne's urban landscape in the 1930s, offering both medical and relaxation services.

\subsection{Bad water: water as a vector of illness}

From 1865 until the end of the 19th century, epidemics of water-borne, gastro-enteric diseases were regularly reported from numerous Swiss cities, including Fribourg and Solothurn (1865), Estavayer and Solothurn (1870), Neuchâtel, Lausanne, Yverdon and Saint Gall (1875), Lausanne- 
Cery and Zurich (1880), and Lucerne (1895). By contrast, not a single epidemic episode of a water-borne illness was mentioned from 1890 to 1950 . Cases were reported in the newspapers when places with high concentrations of people were hit, such as military barracks, hospitals and buildings. The investigations on the causes of these epidemics allowed pointing to health problems in other sections of the population. For example, the typhus epidemic in a military barrack of Solothurn in 1865 allowed the media to underline the presence of an epidemic in the adjacent neighborhood (GL, 24 November 1865:1).

In 1880, the British Medical Journal mentioned the outbreak of typhus in Switzerland; the GL immediately reacted, publishing a note that denied the "absurd" information about the outbreak; linking the quality of water to Switzerland as a country, the GL remembered that "there is not, on Earth, a country possessing a purer and a fresher water than Switzerland" (GL, 28 July 1880:2, own translation). Notwithstanding this denial, a certain consciousness of the links between water and hygiene was already present in Switzerland, particularly in Lausanne. In fact, in 1865 a group of citizens led by a medical doctor and two engineers publicly proposed a list of measures to fight against "the causes of unhealthiness which could become a problem for the population" (GL, 18 October 1865:3, own translation). Among the proposed measures many concerned water with suggestions including a reform of the city's water distribution system, an increase of the quantity of distributed water per inhabitant, a monitoring and cleaning of sewers, and even the idea to "automatically inspect those dwellings that are renowned for being unhealthy" (GL, 18 October 1865:3).

\subsection{New water: establishment of water infrastructure at the urban and regional level}

The construction of water infrastructure was continuous and accelerated from 1850 until 1910. At the beginning, municipalities and private companies only invested in the largest components of the infrastructure, such as water catchment, transport and distribution through fountains. Most cities preferred investing in public fountains, such as Aarau, where springwater was collected and distributed through 450 fountains in 1860. In big cities such as Geneva, however, water and gas had been brought into new buildings since the 1860s. At the time, water pipes were set up everywhere in Switzerland, especially in urban areas. The investment boom in water infrastructure was also reflected in many advertisements from enterprises offering pipes, fountains and other materials and their installation to municipalities and owners of private buildings.

In the same period, numerous articles and announcements informed the population about the decisions of municipalities to build piped water networks. The sanitary and economic reasons for bringing pressurized drinkable water to urban settlements were stated implicitly and were rarely highlighted.
By contrast, the available budgets as well as the financial instruments employed to acquire water were often mentioned in great detail. Debates focused on the role of the public administration and the financial implications rather than on the need for tap water itself. In 1875, for example, the municipality of Lausanne negotiated and finally accepted a contract with a private company to entrust it with the distribution of water to the city dwellers. The political struggle around this contract pitted supporters of free market principles against the proponents of the view that water constitutes a public good and as such should be provided by the municipality. The former argued that the contract would allow the municipality to preserve and improve the health of the population without having to run into debts, as the private company would finance the construction of the piped network (GL, 6 April 1875:3; GL, 25 August 1875:3; GL, 20 September 1875:2). Not all Swiss cities followed the same way. Indeed, in the same year (1875), the municipality of Lucerne built its water infrastructure without the participation of private capital, while in the surroundings of Montreux two citizens' committees were created to self-finance the needed infrastructure.

Unlike the fountain-based water distribution networks, pressurized tap water networks with water points at the dwelling level became widely diffused in the biggest cities only at the beginning of the 20th century. In 1900, tap water was seen as a sign of progress and well-being: "Water, force and light soon will come to Lausanne and will thus increase its well-being" (GL, 24 October 1900:3); or thanks to the arrival of pressurized water "Vallorbe will have nothing to envy the great cities" (GL, 13 December 1900:3). By 1915, however, tap water had already become part of the daily routine: if there is no water coming from the tap, and one has to go to the public fountain, "the people of today are completely distraught" (GL, 30 January 1915:1). Yet, the complete modernization of dwellings and buildings and full access to tap water was attained only by 1950 , when fountains also started to disappear from the urban landscape.

From 1900, a trend toward the de-privatization or "municipalization" of urban water provision was discernible. The municipality of Lausanne, for example, acquired the two private companies in charge of urban drinking and industrial tap water during the first decade of the 1900s. This created a new and adjustable source of revenue for the municipality: When the city was in need of capital, such as in 1920, it could increase the price of water without having to raise taxes. A similar path of de-privatization was followed by the municipality of Fribourg in the 1940s. However, these processes did not go unchallenged. Particularly right-wing political actors opposed the existence of close links between municipal water utilities and the public administration. For instance, the political right supported the fusion of Geneva and its neighboring smaller municipalities that took place in 1930 as it implied a reorganization of the public utilities (water, gas and electricity) to become "healthily" managed by an autonomous 
board of directors partially formed by technicians "independent from parties" (GL, 10 May 1930:3).

\subsection{Lacking water: drought, increases in water demand, pollution}

Numerous statements in the studied newspapers concerned droughts, especially in the Jura mountain chain (1865), in Bern and Vevey (1885), in Lausanne (1895, 1900), in Payerne and Château-d'Oex (1900), and in Couvet (1910). The drought of 1865 in Jura and Franches-Montagnes was seen as particularly rough because the required water had to be "painfully" transported over long distances (GL, 5 January 1865:1). Subsequent droughts were addressed through rationing measures, as the configuration of the water networks allowed their managers to turn off the taps. Nevertheless, before and during the rationing periods, the population was strongly encouraged to use less water. These encouragements rarely became coercive measures. An exception is the severe drought of 1900 in Lausanne, when buckets and watering cans were requisitioned by public authorities during the rationing period.

Urban water demand has constantly increased since the second half of the 19th century, mainly due to increases in the urban population, changes in lifestyle and the use of pressurized water for industrial purposes (including as an energy source). In numerous urban areas, this increase in demand caused reductions in the quantities of water available, and the reaction was to look for new sources of water, firstly from springs as well as river and lake water, and to exponentially build new infrastructure. For example, in Lausanne numerous water network extensions were studied and/or realized in 1870 (unknown springs), 1875 (Lac de Bret), 1895-1900 (Pays-d'Enhaut), and 1910 (Lake Arnen). This extension of exploited water sources ceased only in 1932, when a water catchment station for Lausanne was established in the Lake of Geneva.

Pollution of water was not an issue until 1950. In fact, even though contaminations of water had existed before, they had been understood as a random phenomenon or the consequence of wilful misconduct. It is in 1950 that water pollution started being depicted as a social problem "which concerns all of us" (GL, 18 February 1950:4) and which is caused by the modern lifestyle. In the statements on water (and especially lake) pollution, society is negatively defined as "over-industrialized" (15 March 1950:1), while water is "over-exploited" (GL, 1 February 1950:1).

\section{Discussion - a genealogy of governmentalities of urban tap water in Switzerland between 1850 and 1950}

Based on our discourse analysis and through the interpretative process described by Foucault (cf. Kendall and Wickham, 1999), we found that biopower and neoliberal govern- mentality were the main forms of governmentality implemented in the urban water distribution sector in Switzerland between 1850 and 1950. Those two ways of conducing conducts seem to vary and sometimes coexist in specific places and events.

Biopower was especially present during the 19th century. The need to control and increase the health of the population was, explicitly or implicitly, one of the main motivations for building water networks. Some institutions, such as military barracks, crystallized the power and control over health, as they concentrated people and allowed for an easier recognition of epidemic phenomena. These places, similar to those which Foucault (1993) indicated as privileged for controlling the individual bodies, seem to emerge as privileged places for monitoring the healthiness of the social body. Nevertheless, public administrations rarely exerted biopower in a direct way in the field of urban water.

First, even when epidemics were identified, the reaction of the public authorities was neither immediate nor homogeneous. For instance, precautions such as boiling water were sometimes recommended (e.g., in Saint Gall in 1875), while in other circumstances (e.g., in Solothurn in 1865) it is not clear whether the public authorities even showed any concern about the affected population. These different degrees of implication could also be explained by the fact that modern bacteriology was only emerging at that time (thanks to the works of Ignaz Semmelweis, John Snow, Louis Pasteur and Robert Koch). Therefore, notions of (water-borne) disease transmission might not have been widespread and understood yet.

Second, although there was some pressure on (municipal) administrations to exert biopower in a more direct way (for instance with the proposal, which was put into practice later, to inspect houses), the public administrations shared the responsibility for health to a varying degree with the market and the individuals. In Montreux, for instance, individuals created associations in order to build their water network themselves. In other cases, such as in Lucerne, the municipality took the responsibility of providing water (and, thus, health) to the population, or delegated this responsibility to the market, as in Lausanne. When the municipalities took back responsibility for water networks, no considerations on public health were mentioned in the debates.

In summary, biopower appears to have been present, but the way of exerting it is subject to variations depending on the place, time and scale. While the Swiss Confederation appears to have exerted a constant biopower on the health of its soldiers, for example, through the monitoring of epidemics on its military barracks, the health of civilians was considered the jurisdiction of the municipal (and eventually cantonal) administrative level, and thus it was handled in variable ways according to local political equilibria.

Forms of neoliberal governmentality seem to have been prevalent during the whole studied period. As mentioned above, neoliberal governmentality has two main compo- 
nents: it implies both governing according to market principles and governing at a distance.

Governing according to market principles was widely and ubiquitously stressed in the statements, independently of the place and time. The budgets needed and used for water network construction and amelioration were detailed, as well as the origin of the finances (loan, taxation, etc.). In addition, a certain number of discussions focused on the different possibilities for financing (e.g., in the case of Lausanne and the contract with private companies) and managing (e.g., in the case of Geneva and the creation of a board of directors) urban water networks. Business considerations, in relation to the tourism industry, were also present in the way the discourse itself was produced (or not), as in the reaction of GL to the article about epidemics in Switzerland published by the British Medical Journal.

By contrast, governing at distance was rarely mentioned. When, in case of drought, people were encouraged to diminish their water consumption, this was a clear example of governing at distance. In addition, the spread of ideologies of progress, modernity, etc. could be an indirect form of governing at a distance, as these ideologies were key elements in supporting the discourse on the construction of water networks. Nevertheless, water was generally managed at no distance (as the managers are often at least partially coincident with the users) and with coercive measures, for instance when buckets and watering cans were requisitioned in case of drought or when water was rationed.

The relation between water and health was nonetheless subject to power at a distance, in the sense that it was strongly individualized and it was generally not subject to direct state intervention. Thus, the individual was made responsible for his/her own consumption of water and especially for the relation between water and his/her own health. The stress on individual responsibility is particularly well illustrated by an example from 1895. In Hellbühl (Lucerne), the tenant of an apartment died because of typhus, and her husband asked for the well's water to be analyzed in order to prove the culpability of the landlord. The landlord refused to believe the results of the chemical analyses and decided that his family should continue drinking the (polluted) water from the house well. Soon thereafter, the entire family of the landlord fell ill and some of its members died (GL, 24 December 1895:3). This example shows that when individuals are given the information, they are simultaneously asked to recognize the disciplinary power of "science" (be it biology, chemistry or something else) and made responsible about their own fate (as their conduct should be adapted to what is rationally admissible according to science). The same way of exerting power was present when citizens were informed of the risk of contamination and they were asked to boil their water before using it in Saint Gall (21 June 1875:2).

\section{Conclusions}

The historical data confirm historical events pointed out in literature about the history of water networks and hygiene in Switzerland, such as the strategies for the construction of water networks (cf. for instance Pflieger, 2009a; Heller, 1979). They are also coherent with regard to the deep relation between water networks and the ideologies of modernity and progress which has been thoroughly analyzed in the domain of urban political ecology of water (cf. Giglioli and Swyngedouw, 2008; Kaika, 2012; Swyngedouw, 2004).

The genealogy of the various forms of hydromentality brings new knowledge to the existing literature on the history of water networks in Switzerland. In particular, our analysis confirms some of the insights which had been pointed out by the geographical and political sciences literature on the institutional arrangements (cf. Pflieger, 2009a, b; Paquier and Pflieger, 2008; Reynard, 2005, 2008; Reynard et al., 2000), and it enriches them with a perspective on the micro-physics of power which had not been investigated yet. In addition, the references to biopower and neoliberal governmentality which had rarely been mentioned in historical literature on Swiss urban water networks (cf. Heller, 1979) are completed by a longitudinal analysis focused on these issues, which contributes nuancing the models proposed by Foucault and highlighting their specificities in the Swiss context.

Both biopower and neoliberal governmentality are present in discourse about the Swiss urban water sector between 1850 and 1950. Nevertheless, the two forms of governmentality present some particularities.

Firstly, they deviate from the models initially proposed by Michel Foucault. Biopower was not always directly exerted on the population, and it was often combined with forms of neoliberal governmentality, i.e., responsibilization of the population and indirect technologies of power allowing for exerting power at a distance. These findings considerably nuance the conclusions formulated by Michel Foucault (1997), namely that biopower would have been exerted through regulatory mechanisms focused on populations and not on individuals, which were left to disciplinary power. In fact, biopower seems to have been exerted in various and nonexclusive ways, forming a continuum from coercive measures (such as rationing) to disciplinary power (exerting its authority through chemical water analysis, for instance) and to responsibilization and governing at a distance (illustrated by the liberty accorded to the individual in the management of his/her health). This is coherent with the elements highlighted by Rabinow and Rose (2006:197), who underline that "[m]odes of subjectification, through which individuals are brought to work on themselves [...] in the name of their own life or health" are also part of biopower.

In addition, neoliberal governmentality was present, as economic principles clearly guided the way of exerting power and individual responsibilization was promoted, but it rarely included governing at a distance, as urban water was 
often managed at no distance and through coercive measures. Nevertheless, this is nuanced by examples in which the responsibility of water provision or of personal health was attributed to individuals, completely discharging public authorities.

Secondly, the ways of exerting power, i.e., the various forms of biopower and neoliberal governmentality and the different combinations of the two varied in place, time and scale. Indeed, our data show great differences on how different municipalities exerted power, as well as between municipalities and the federal level. In addition, the longitudinal analysis showed that the concerns of populations and authorities, as well as the way of exerting power, changed over time.

Our research presents two major limits, both linked to the chosen methodology, that could be overcome by further research. Firstly, it is not clear if the employed method is coherent or not vis-à-vis the methods implemented by Foucault himself. The soon to be released archived files of Foucault from the French National Library should cast light on this point. In addition, further research should be helpful to shed light on the usefulness of the method, i.e., to show if other, more conventional discourse analysis techniques would obtain the same results or not. Secondly, our research focused on the archives of two newspapers from the French-speaking part of Switzerland, and more precisely from Lausanne. Even though the statements that they contain concern all Switzerland, and they are coherent vis-à-vis the results of previous historical research, a regional bias in the selected data cannot be excluded. Further research on the archives of newspapers from other Swiss linguistic regions could thus be useful to better define the reach of the statements analyzed in this study.

The nuances that our results suggest with regard to Foucault's conceptualizations of the different forms of governmentality pose numerous empirical and theoretical questions that might be of interest for further research. In particular, it would be pertinent to investigate whether the highlighted coexistence of biopower, disciplinary power and early forms of neoliberal governmentality is specific to Switzerland in general or only to the establishment of modern water networks in the country. The reasons of a seemingly small presence of disciplinary power in the urban water sector in Switzerland could also be investigated. Finally, the presence of neoliberal governmentality and its technologies of power before the widely studied transposition of economic neoliberalism to politics which have taken place since the 1970s invites further research to be conducted in order to rethink the classification and periodization of the different forms of governmentality that have been proposed by Foucault.
Acknowledgements. The authors are grateful to Daniel Speich, Anna Zimmer, Géraldine Pflieger, Emmanuel Reynard, Benedikt Korf and three anonymous reviewers for their valuable comments.

The authors would like to acknowledge the helpful work provided by the research assistants who collaborated on this research, especially Mirela Travnjak.

This research was carried on thanks to the financial support of the Canton Vaud and of the Institute of Geography and Sustainability of the University of Lausanne.

Edited by: B. Korf

Reviewed by: three anonymous referees

\section{References}

Agrawal, A.: Environmentality: Community, Intimate Government, and the Making of Environmental Subjects in Kumaon, India, Curr. Anthropol., 46, 161-190, doi:10.1086/427122, 2005.

Babu, A.: Governmentality, Active Citizenship and Marginalisation: The Case of Rural Drinking Water supply in Kerala, India, Asian Social Science, 5, 89-98, 2009.

Benjaminsen, T. A. and Svarstad, H.: Qu'est-ce que la "political ecology"?, Natures Sciences Sociétés, 17, 3-11, 2009.

Brand, P.: Green subjection: the politics of neoliberal urban environmental management, Int. J. Urban Regional, 31, 616-632, 2007.

Church, C. H.: The politics and government of Switzerland, Macmillan, Basignstoke, United Kingdom, 2004.

Dean, M.: Critical and effective histories: Foucault's methods and historical sociology, Routledge, London, United Kingdom, 1994.

De La Harpe, P.: Recherches sur les divers modes de propagation de la fièvre typhoïde dans le canton de Vaud (Suisse), Imprimerie Borgeaud, Lausanne, Switzerland, 1867.

Delamuraz, J.-P.: 1989 - Allocution du Président de la Confédération Jean-Pascal Delamuraz à l'occasion de la Fête nationale, available at: http://www.admin.ch/br/dokumentation/media/nat/ 00178/index.html?lang=fr\#, 1989.

Dirlewanger, D.: Les services industriels de Lausanne?: la révolution industrielle d'une ville tertiaire (1896-1901), Antipodes, Lausanne, Switzerland, 1998.

Duc, G.: La trajectoire d'une famille d'industriels valaisans du XIXe siècle?: les Dumont et les filières techniques de la deuxième Révolution industrielle, Annales valaisannes?: bulletin trimestriel de la Société d'histoire du Valais romand, 153-167, available at: http://doc.rero.ch/lm.php?url=1000,43, 19,20110112163208-YS/I_N177_2003_153.pdf, 2003a.

Duc, G.: Les services industriels de la Ville de Sion (1867-1914)?: reflet des mutations d'un chef-lieu rural, Editions à la Carte, Sierre, Switzerland, 2003b.

Ferguson, J. and Gupta, A: Spatializing states: toward an ethnography of neoliberal governmentality, Am. Ethnol., 29, 981-1002, 2002.

Fletcher, R.: Neoliberal Environmentality: Towards a Poststructuralist Political Ecology of the Conservation Debate, Conservation \& Society, 8, 171-181, 2010.

Foucault, M. (Ed.): Politiques de l'habitat (1800-1850), Paris: C.O.R.D.A., Paris, France, 1977.

Foucault, M.: Le nouveau contrôle social, Université Paris 8, Vincennes-Saint-Denis, France, available at: http://www. archives-video.univ-paris8.fr/video.php?recordID=111, 1979. 
Foucault, M.: "Governmentality" (lecture at the Collège de France, 1 February 1978), in: The Foucault Effect: Studies in Governmentality, edited by: Burchell, G., Gordon, C., and Miller, P., Harvester Wheatsheaf, Hemenl Hempstead, United Kingdom, 87-104, 1991.

Foucault, M.: L'archéologie du savoir, Gallimard, Paris, France, 1992.

Foucault, M.: Surveiller et punir?: naissance de la prison, Gallimard, Paris, France, 1993.

Foucault, M.: Il faut défendre la société?: cours au Collège de France, 1975-1976, Gallimard/Seuil, Paris, France, 1997.

Foucault, M.: The Birth of Biopolitics: Lectures at the Collège de France 1978-79, edited by: Senellart, M., Ewald, F., and Fontana, A., Palgrave Macmillan, New York, USA, 2008.

Foucault, M.: Security, Territory, Population: Lectures at the College de France 1977-1978, edited by: Senellart, M., Ewald, F., and Fontana, A., Palgrave Macmillan, New York, USA, 2009.

Geiger, W. and OFEV: Des responsabilités pour le "château d'eau de l'Europe.", available at: http://www.bafu.admin.ch/ dokumentation/fokus/00138/01370/index.html?lang=fr, 2003.

Giglioli, I. and Swyngedouw, E.: Let's Drink to the Great Thirst! Water and the Politics of Fractured Techno-natures in Sicily, Int. J. Urban Regional, 32, 392-414, doi:10.1111/j.14682427.2008.00789.x, 2008.

Hauser, H.: La position géographique de la Suisse, Ann. Geogr., 25, 413-428, doi:10.3406/geo.1916.8709, 1916.

Hellberg, S.: Water, life and politics: Exploring the contested case of eThekwini municipality through a governmentality lens, Geoforum, 56, 226-236, doi:10.1016/j.geoforum.2014.02.004, 2014.

Heller, G.: Propre en ordre: Habitation et vie domestique 1850: 1930: l'exemple vaudois, Editions d'En-Bas, Lausanne, Switzerland, 1979.

Heynen, N., Kaika, M., and Swyngedouw, E. (Eds.): In the nature of cities?: urban political ecology and the politics of urban metabolism, Routledge, London, United Kingdom, 2006.

Hood, C.: Emerging issues in public administration, Public Admin., 73, 165-183, 1995.

Humair, C.: Ville, tourisme et transport : la compagnie du chemin de fer Lausanne-Ouchy (1869-1914), Entreprises et histoire, 47, 11, doi:10.3917/eh.047.0011, 2007.

Kaika, M.: Constructing scarcity and sensationalising water politics: 170 days that shook Athens, Antipode, 35, 919-954, 2003.

Kaika, M.: City of flows: Modernity, nature, and the city, Routledge, New York, United States, 2012.

Kendall, L. and Wickham, G. M.: Using Foucault's methods, Sage, London, United Kingdom, 1999.

Kriesi, H.: Le système politique suisse, Economica, Paris, France, 1998.

Lebeau, R.: Zurich, métropole de la Suisse, Revue de géographie de Lyon, 35, 7-47, doi:10.3406/geoca.1960.2378, 1960.

Lemke, T.: "The birth of bio-politics": Michel Foucault's lecture at the Collège de France on neo-liberal governmentality, Econ. Soc., 30, 190-207, doi:10.1080/713766674, 2001.

Lijphart, A.: Consensus and Consensus Democracy: Cultural, Structural, Functional, and Rational-Choice Explanations, Scand. Polit. Stud., 21, 99-108, doi:10.1111/j.14679477.1998.tb00007.x, 1998.

Linder, W.: Swiss democracy: Possible solutions to conflict in multicultural societies, Palgrave Macmillan, New York, USA, 2010.
Loutan, L. and Genton, B.: Edito: Voyages, globalisation et accès à la santé, Revue Médicale Suisse, 65, available at: http://revue. medhyg.ch/article.php3?sid=31402, 2006.

Michelet, J.: La montagne (7e édition), A. Lacroix, Verboeckhoven, Paris, France, available at: http://visualiseur.bnf.fr/ CadresFenetre?O=NUMM-29493\&I=1\&M=notice, 1868.

Morax: Rapport annuel de M. le Dr. Morax. Président de la société vaudoise de médecine, in : Bulletin de la Société médicale de la Suisse romande, Librairie Rouge et Dubois, Lausanne, Switzerland, 72-87, 1868.

Mornati, F.: La collaboration de Pareto avec la Gazette de Lausanne, Revue européenne des sciences sociales, 48, 71-88, 2010.

Page, B.: Paying for water and the geography of commodities, T. I. Brit. Geogr., 30, 293-306, doi:10.1111/j.14755661.2005.00172.x, 2005.

Paquier, S. and Pflieger, G.: L'eau et les services industriels de Genève : aux sources du modèle suisse des services urbains, Entreprises et histoire, 50, 36, doi:10.3917/eh.050.0036, 2008.

Pfister, C.: Klimageschichte der Schweiz, 1525-1860: Das Klima der Schweiz von 1525-1860 und seine Bedeutung in der Geschichte von Bevölkerung une Landwirtschaft, Haupt, Bern, Switzerland, 1988.

Pflieger, G.: L'eau des villes?: aux sources des empires municipaux, Presses polytechniques et universitaires romandes, Lausanne, Switzerland, 2009a.

Pflieger, G.: De la naissance des réseaux d'eau à l'hydroélectricité?: l'essor du municipalisme en Suisse, Espaces et sociétés, 139, 39, doi:10.3917/esp.139.0039, 2009b.

Rabinow, P. and Rose, N.: Biopower today, BioSocieties, 1, 195217, 2006.

Ratti, R.: Leggere la Svizzera, Casagrande editore, Lugano, Switzerland, 1995.

Reynard, E.: La contribution des régimes institutionnels des ressources à une gestion durable des eaux en milieu urbain, in: Enjeux du développement urbain durable: transformations urbaines, gestion des ressources et gouvernance, edited by: Da Cunha, A., Knoepfel, P., Leresche, J.-P., and Nahrath, S., Presses polytechniques et universitaires romandes, Lausanne, Switzerland, 257-280, 2005.

Reynard, E.: Transporter l'eau?: regards croisés sur les réseaux urbains et ruraux de l'eau en Suisse, Flux, 2, 27-38, available at: http://www.cairn.info/revue-flux-2008-2-page-27.htm, 2008.

Reynard, E., Mauch, C., and Thorens, A.: Screening historique des régimes institutionnels de la ressource eau en Suisse entre 1870 et 2000, Working Paper 2000/6, IDHEAP, Lausanne, Switzerland, available at: http://www-idheap. unil.ch/idheap.nsf/ed6f7e242e9019a7c12569ff0038e8f9/ a6b03265f659b0e0c1256b29004f9d77/FILE/WP-6\%202000\% 20eaux.pdf, 2000.

Schädler, B.: Klimawandel?: Geht uns das Wasser aus? = Climate Change?: Are we Running out of Water? Changement climatique?: Bientôt à sec?, GWA, 88, 763-769, available at: http: //cat.inist.fr/?aModele=afficheN\&cpsidt=20708401, 2008.

Schorer, M.: Extreme Trockensommer in der Schweiz und ihre Folgen für Natur und Wirtschaft, Geographica Bernensia, G40, Geographisches Institut der Universität, Bern, Switzerland, 1992.

Swyngedouw, E.: Power, nature, and the city. The conquest of water and the political ecology of urbanization in 
Guayaquil, Ecuador: 1880-1990, Environ. Plann. A, 29, 311332, doi:10.1068/a290311, 1997.

Swyngedouw, E.: Modernity and hybridity: nature, regeneracionismo, and the production of the Spanish waterscape, 18901930, Ann. Assoc. Am. Geogr., 89, 443-465, 1999.

Swyngedouw, E.: Social power and the urbanization of water?: flows of power, Oxford University Press, Oxford, United Kingdom, 2004.

Swyngedouw, E.: The Political Economy and Political Ecology of Hydro-Social cycle, Journal of Contemporary Water Research and Education, 142, 56-60, 2009.
Tissot, L.: Naissance d'une industrie touristique?: les Anglais et la Suisse au XIXe siècle, Payot, Lausanne, Switzerland, 2000.

von Schnitzler, A.: Citizenship Prepaid: Water, Calculability, and Techno-Politics in South Africa, J. S. Afr. Stud., 34, 899-917, doi:10.1080/03057070802456821, 2008.

Vouilloz Burnier, M.-F.: Bienfaits et méfaits de l'eau sur la santé?: l'exemple du Valais aux XIXe et XXe siècles, Histoire des Alpes $=$ Storia delle Alpi = Geschichte der Alpen, 13, 163-179, 2008. 